JOTE Volume 2 Nomor 1 Tahun 2020 Halaman $1-8$ JOURNAL ON TEACHER EDUCATION

Research \& Learning in Faculty of Education

PNIVERSITAS

\title{
Penerapan Pendekatan Keterampilan Proses Sains Berorientasi Problem-Based Instruction untuk Meningkatkan Hasil Belajar Siswa Kelas XII IA 1 SMA Negeri 2 Maumere
}

\author{
Hendrikus Hadir \\ SMA Negeri 2 Maumere, Sikka, NTT \\ Email: hadirhendrik66@gmail.com
}

\begin{abstract}
Abstrak
Telah dilakukan penelitian tindakan kelas untuk memperbaiki dan meningkatkan hasil belajar siswa melalui penelitian tindakan kelas dengan pendekatan Keterampilan Proses Sains (KPS) Berorientasi Problem Based Instruction (PBI). Penelitian ini dilaksanakan di kelas XII IA 1 SMA Negeri 2 Maumere Tahun Pelajaran 2019/2020, dengan jumlah siswa 30 orang. Penelitian ini bertujuan untuk mengetahui apakah pembelajaran dengan menggunakan Pendekatan Keterampilan Proses Sains (KPS) Berorientasi PBI dapat meningkatkan hasil belajar dan aktivitas belajar siswa. Fokus dalam penelitian ini adalah hasil belajar kimia yang meliputi aspek kognitif, afektif, psikomotorik, selain juga aktivitas belajar dan keterampilan proses sains siswa, serta kinerja guru. Hasil penelitian menunjukkan terjadinya peningkatan hasil belajar siswa berturut-turut adalah $70,33,80,63$ dan 89,88. Aktivitas belajar siswa juga mengalami peningkatan yaitu dengan skor rata-rata 65,21 pada siklus I naik menjadi 75,88 pada siklus II serta meningkat pada siklus III menjadi 85,05. Dapat disimpulkan bahwa pembelajaran kimia melalui Pendekatan Keterampilan Proses Sains (KPS) Berorientasi PBI dapat meningkatkan hasil belajar serta aktivitas belajar siswa.
\end{abstract}

Kata Kunci: Keterampilan Proses Sains, Problem Based Instruction, Hasil Belajar Siswa

\begin{abstract}
Classroom action research has been carried out to improve and enhance student learning outcomes through classroom action research with a Problem Based Instruction Oriented Science Process Skills (PBI) approach. This research was conducted in class XII IA 1 SMA Negeri 2 Maumere for the 2019/2020 academic year, with 30 students. This study aims to determine whether learning using the PBI-Oriented Science Process Skills (KPS) approach can improve student learning outcomes and learning activities. The focus in this study is the learning outcomes of chemistry which include cognitive, affective, psychomotor aspects, as well as student learning activities and science process skills, as well as teacher performance. The results showed that the increase in student learning outcomes was $70.33,80.63$ and 89.88 , respectively. Student learning activities also increased, namely with an average score of 65.21 in the first cycle increasing to 75.88 in the second cycle and increasing in the third cycle to 85.05. It can be concluded that chemistry learning through the PBI-Oriented Science Process Skills (KPS) approach can improve student learning outcomes and learning activities.
\end{abstract}

Kata Kunci: Science Process Skills, Problem Based Instruction, Student Learning Outcomes 


\section{PENDAHULUAN}

Salah satu masalah yang dihadapi dunia pendidikan kita adalah masalah lemahnya proses pembelajaran (Sudarman, 2007). Dalam pembelajaran kimia siswa yang mengalami hambatan terlihat bersikap pasif, apatis, dan masa bodoh, sedangkan siswa yang tidak mengalami kesulitan terlihat aktif, bersemangat, kritis, dan berkonsentrasi dalam pembelajaran. Ini merupakan kesenjangan yang belum teratasi secara tuntas. Dalam proses pembelajaran siswa kurang didorong untuk mengembangkan kemampuan berpikir. Proses pembelajaran di kelas diarahkan kepada kemampuan anak untuk menghafal informasi.

Otak anak dipaksa untuk mengingat dan menimbun berbagai informasi tanpa dituntut memahami informasi yang diingatnya itu untuk menghubungkan dengan kehidupan sehari-hari. Akibatnya, ketika anak didik lulus dari sekolah mereka pintar teoritis tetapi mereka miskin aplikasi. Mata pelajaran kimia yang diajarkan di sekolah bertujuan untuk membekali siswa agar mampu mengembangkan kemampuan observasi dan eksperimentasi serta berfi kir taat asas. Belajar kimia tidak hanya terfokus pada hasil (produk) tapi lebih diutamakan pada kemampuan untuk melakukan proses (Abdullah, 2007). Proses dalam hal ini merupakan interaksi semua komponen atau unsur pembelajaran yang saling berhubungan untuk mencapai tujuan salah satu indikasinya adalah keberhasilan siswa untuk menghadapi persoalan dalam kehidupan sehari-hari.

Kompetensi lulusan suatu jenjang pendidikan, hendaknya sesuai dengan tujuan pendidikan nasional, mencakup komponen pengetahuan, keterampilan, kemandirian, kreativitas, kesehatan akhlak, ketakwaan, dan kewarganegaraan. Siswa tidak hanya mengetahui fakta, konsep atau prinsip, tetapi juga terampil untuk menerapkan pengetahuannya dalam menghadapi masalah dalam kehidupan dan teknologi. Untuk dapat menghasilkan lulusan yang kompeten dan sesuai dengan tuntutan zaman, maka perlu digunakan pendekatan dan metode belajar mengajar yang sesuai. Salah satu alternatif pembelajaran yang bisa menumbuhkan keterampilan proses sains adalah pembelajaran berbasis masalah yaitu dengan menggunakan Pendekatan Keterampilan Proses Sains (KPS) Berorientasi PBI (Problem Based Instruction) dapat digunakan sebagai salah satu pendekatan pada pembelajaran kimia. Pembelajaran tersebut akan lebih menarik bagi siswa karena proses pembelajarannya berbeda. Dengan pembelajaran berbasis masalah siswa diarahkan pada masalah kontekstual (Abdullah, 2007).

Masalah yang diberikan yaitu konteks dunia nyata, mengandung unsur penemuan, memuat petunjuk bagi siswa sebagai pengarah, dan bertujuan untuk mengembangkan pengetahuan mengenai esensi dari suatu konsep karena selain menguasai konsep-konsep kimia, siswa juga diharapkan memiliki keterampilanketerampilan proses yang digunakan para ahli dalam memperoleh dan mengembangkan kurikulum serta dapat memecahkan suatu permasalahan dalam kehidupan sehari-hari. Aktivitas siswa dapat dilihat dari keterampilanketerampilan proses sains yang dimilikinya. Keterampilan-keterampilan proses sains harus ditumbuhkan dalam diri siswa SMA sesuai dengan taraf perkembangan pemikirannya. Pelajaran-pelajaran di sekolah dikembangkan berdasar tuntutan keterampilan proses, termasuk mata pelajaran kimia. IImu kimia dibangun melalui pengembangan keterampilan proses sains misalnya: 
mengobservasi, mengklasifi kasi, memprediksi, mengukur, menyimpulkan, dan mengkomunikasikan (Dimyati dan Mudjiono, 2002).

Berdasarkan hasil dari beberapa penelitian mengenai Pendekatan Keterampilan Proses Sains maupun Problem Based Instruction (PBI) antara lain menurut Dwi Maretnowati (2007) menunjukkan adanya peningkatan hasil belajar kimia pokok materi sistem koloid melalui Pendekatan Problem Based Instruction (PBI) dengan menggunakan kartu masalah di kelas XI Semester 2 SMA N I Karangpandan Tahun Pelajaran 2006/2007 yang ditandai dengan ketuntasan belajar secara klasikal ; Akhya Shofa (2008) menunjukkan bahwa pembelajaran kimia dengan pendekatan keterampilan proses pada materi termokimia dapat meningkatkan hasil belajar siswa maupun kreativitas siswa yang ditandai dengan ketuntasan hasil belajar klasikal siswa serta kreativitas siswa yang meningkat. Dengan melihat hasil penelitian tersebut peneliti ingin meneliti apakah kombinasi antara Pendekatan Keterampilan Proses dengan PBI (Problem Based Instruction) akan dapat meningkatkan hasil belajar siswa. Sehingga peneliti ingin mengadakan penelitian dengan Pendekatan Keterampilan Proses Sains Berorientasi PBI (Problem Based Instruction) yang oleh sepengetahuan peneliti belum ada penelitian skripsi tentang hal tersebut.

Masih banyaknya masalah yang dihadapi dalam proses pembelajaran kimia berdampak pada hasil belajar siswa yang rendah. Berdasarkan informasi hasil belajar siswa pada tahun 2018, bahwa rata-rata nilai ulangan harian kimia kelas XII IA 1 Semester I SMA Negeri 2 Maumere pada pokok bahasan sifat koligatif larutan belum mencapai batas ketuntasan belajar yaitu masih mencapai $38,33 \%$. Sedangkan rata-rata nilai ulangan harian pertama kimia kelas XII IA 1 Semester I SMA Negeri 2 Maumere juga masih rendah yaitu 65,95. Permasalahan yang dikaji dalam penelitian ini adalah apakah pembelajaran melalui Pendekatan Keterampilan Proses Sains (KPS) Berorientasi PBI (Problem Based Instruction) dapat meningkatkan hasil belajar siswa dan aktivitas belajar siswa. Tujuan umum dari penelitian ini adalah untuk mengetahui apakah pembelajaran dengan menggunakan Pendekatan Keterampilan Proses Sains (KPS) Berorientasi PBI (Problem Based Instruction) dapat meningkatkan hasil belajar dan aktivitas belajar siswa kelas XII SMA Negeri 2 Maumere.

Sedangkan tujuan khususnya adalah Ketuntasan hasil belajar kognitif secara klasikal siswa mencapai $85 \%$ dan tuntas individunya apabila siswa secara individu memperoleh nilai minimal 75 , untuk ketuntasan klasikal hasil belajar psikomotorik diharapkan persentase minimal sebesar $85 \%$, sedangkan secara individu diharapkan $80 \%$ untuk setiap aspek yang diamati serta persentase minimal afektif siswa, aktivitas siswa serta keterampilan proses sains yang diharapkan sebesar $85 \%$, sedangkan secara individu diharapkan $70 \%$ untuk setiap aspek yang diamati.

\section{METODE}

Penelitian ini dilaksanakan di SMA Negeri 2 Maumere pada bulan Juli dengan subyek penelitiannya adalah siswa kelas XII IPA IA 1 semester I Tahun Pelajaran 2019/2020 dengan jumlah siswa dalam satu kelas yaitu 30 siswa yang terdiri dari 10 siswa laki-laki dan 20 siswa perempuan. Fokus dalam penelitian ini adalah hasil belajar kimia siswa yang dapat diukur dengan menggunakan tes 
setiap akhir siklus (kognitif), afektif dan psikomotorik dengan lembar observasi, proses pembelajaran yang berlangsung apakah sudah dapat merangsang siswa untuk berpikir kritis dalam menyelesaikan suatu permasalahan, aktivitas belajar siswa dalam pembelajaran seperti yang direncanakan, serta keterampilan proses sains siswa apakah mengalami peningkatan serta kinerja guru dalam melakukan pembelajaran apakah sudah sesuai dengan rencana pembelajaran yang disusun.

Teknik pengumpulan data dalam penelitian ini adalah metode tes dimana untuk mengukur hasil belajar kognitif siswa setelah tes akhir siklus, metode angket untuk mengetahui tanggapan siswa terhadap pembelajaran yang telah dilakukan, metode observasi untuk mengetahui aktivitas belajar siswa,keterampilan proses sains siswa, hasil belajar afektif, psikomotorik siswa selama proses pembelajaran serta kinerja guru.

Instrumen dalam penelitian ini terdiri dari silabus, rencana pelaksanaan pembelajaran, LKS, lembar observasi afektif, psikomotorik, aktivitas, keterampilan proses sains siswa serta tes akhir siklus yang sebelumnya sudah diujicoba terlebih dahulu. Indikator kinerja pada penelitian ini adalah bahwa penelitian akan dinyatakan berhasil apabila hasil belajar pada siswa kelas XII IPA IA 1 pada pokok bahasan sifat koligatif larutan secara individu memperoleh nilai minimal 75.

Dikatakan tuntas belajar klasikal apabila dari siswa satu kelas yang memperoleh nilai 75 atau lebih mencapai $85 \%$. Untuk ketuntasan hasil belajar psikomotorik secara klasikal persentase minimal yang diharapkan sebesar $85 \%$ sedangkan secara individu diharapkan $80 \%$ siswa aktif mengikuti proses pembelajaran untuk setiap aspek yang diamati. Untuk hasil belajar afektif, serta aktivitas belajar siswa, keterampilan proses sains siswa secara klasikal persentase minimal yang diharapkan sebesar $85 \%$, sedangkan secara individu diharapkan $70 \%$ untuk setiap aspek yang nilai.

\section{HASIL DAN PEMBAHASAN}

Data hasil belajar kognitif siswa ditunjukkan dengan nilai yang diperoleh siswa setelah mengikuti tes akhir siklus I,II, maupun III. Data rata-rata hasil belajar kognitif siswa dari siklus I sampai siklus III disajikan

\section{Hasil belajar afektif}

Hasil belajar afektif diperoleh dari sikap siswa selama pembelajaran berlangsung. Data rata-rata hasil belajar afektif siswa dari siklus I sampai siklus III

\section{Hasil belajar psikomotorik}

Hasil belajar psikomotorik siswa diperoleh dari observasi saat siswa melakukan praktikum. Data rata-rata hasil belajar afektif siswa dari siklus I sampai siklus III.

\section{Aktivitas siswa}

Penilaian Aktivitas siswa selama proses pembelajaran berdasarkan hasil observasi 


\section{Hasil observasi keterampilan proses sains siswa}

Hasil analisis masing-masing aspek dari keterampilan proses sains pada siklus I, II, dan III dapat dilihat dari tabel 1

\section{Hasil observasi kinerja guru}

Data hasil observasi kinerja guru selama proses pembelajaran berlangsung diperoleh dari observasi yang dilakukan oleh observer. Berdasarkan hasil penelitian dapat diketahui bahwa penggunaan Pendekatan Keterampilan Proses Sains Berorientasi Problem Based Instruction (PBI) dapat meningkatkan hasil belajar dan aktivitas belajar siswa. Hal ini dikarenakan dengan menggunakan Pendekatan Keterampilan Proses Sains Berorientasi PBI, siswa tidak hanya mendengarkan ceramah dari guru mengenai suatu materi saja, namun siswa dapat mengalami proses untuk mendapatkan konsep, rumus, atau keterangan tentang sesuatu sehingga siswa dapat memahaminya, merangsang sikap ingin tahu siswa, pengertian siswa tentang suatu konsep atau prinsip lebih mantap sehingga memungkinkan siswa untuk dapat menerapkannya dalam masalah lain yang lebih relevan terutama masalah yang berkaitan dengan kehidupan seharihari. Melalui Pendekatan Keterampilan Proses Sains Berorientasi PBI siswa akan memperoleh pengertian yang benar-benar dihayati karena siswa sendiri yang menemukan konsep atau generalisasi dari hasil pekerjaannya (hasil pengamatan dan penemuannya) sehingga dapat menjadi salah satu faktor untuk menumbuhkan motivasi intrinsik pada diri siswa. Dengan adanya motivasi dalam diri siswa ini, akan memberi semangat siswa untuk giat dalam belajar, sehingga hasil belajarnya meningkat. Penelitian tindakan kelas ini dilaksanakan dalam tiga siklus. Pembahasan untuk pelaksanaan tiap siklusnya adalah sebagai berikut:

\section{Siklus I}

Pelaksanaan siklus I ini membutuhkan waktu 7 jam pelajaran ( 7 x 45 menit) yang terbagi dalam 4 kali pertemuan yang diakhiri dengan tes akhir siklus I. Pada awal pertemuan guru juga membagi kelompok yang nantinya digunakan untuk kelompok praktikum maupun kelompok diskusi dimana pada satu kelompok terdiri dari 4-5 siswa. Guru juga membagikan LKS yang berisi permasalahanpermasalahan dalam kehidupan sehari-hari yang berkaitan dengan materi sifat koligatif larutan. Setelah kelompok terbentuk, maka setiap kelompok mendapat bagian untuk menjawab salah satu permasalahan yang ada proses pembelajaran berlangsung, sehingga guru tidak mengetahui mana siswa yang kurang jelas terhadap materi yang diajarkan, (2) pengelolaan kelas dari guru yang belum baik, (3) motivasi siswa yang masih kurang dalam mengikuti pembelajaran, (4) aspek psikomotorik yang belum terukur sehingga nilai psikomotor tiap-tiap siswa belum dapat diketahui karena belum adanya kegiatan praktikum.

\section{Siklus II}

Perencanaan dalam pelaksanaan proses pembelajaran pada siklus II mengacu pada hasil refl eksi pada siklus I. Pelaksanaan siklus 2 ini membutuhkan waktu 8 
jam pelajaran ( $8 \times 45$ menit) yang terbagi dalam 5 kali pertemuan yang diakhiri dengan tes akhir siklus II. Pada awal pertemuan untuk siklus II ini diawali dengan pelaksanaan praktikum penurunan titik beku larutan dimana sebelumnya siswa disuruh mempelajari sendiri terlebih dahulu tentang penurunan titik beku larutan, sehingga diharapkan siswa dapat melaksanakan praktikum dengan baik. Guru lebih memilih praktikum terlebih dahulu dibandingkan pemberian materi karena dengan pelaksanaan praktikum terlebih dahulu diharapkan siswa dapat melatih keterampilan proses untuk berfi kir menemukan konsep dari penurunan titik beku larutan, keterampilan menggunakan alat-alat, keterampilan untuk membuat kesimpulan dari hasil pengamatan, selain itu dengan praktikum siswa dapat melakukan pengamatan secara langsung sehingga siswa merasa puas akan hasil pengamatan dan penemuannya sebagai salah satu faktor untuk menumbuhkan motivasi intrinsik pada diri siswa itu sendiri. Dari pelaksanaan praktikum diperoleh rata-rata skor psikomotorik siswa sebesar 81,25 dengan kriteria baik. Hasil tes pada akhir siklus II diperoleh rata-rata nilainya sebesar 80,63 dengan demikian sudah sesuai dengan yang ditargetkan, akan tetapi siswa yang dinyatakan tuntas baru mencapai $73 \%$ dengan rincian 22 siswa yang sudah tuntas individu dan 8 siswa yang belum tuntas. Hasil belajar afektif siswa dari siklus I ke siklus II mengalami peningkatan rata-rata sebesar 8,79\% yang semula rata-rata nilai afektif siswa sebesar 67,99 meningkat menjadi 73,97. Namun apabila dilihat dari hasil tersebut, maka belum memenuhi target sehingga perlu ditingkatkan lagi ke siklus berikutnya. Pada Siklus kinerja guru selama proses pembelajaran setelah dianalisis ternyata diperoleh skor 64,5. Adapun persentase kinerja guru sebesar $80,63 \%$ dan termasuk kriteria baik. Berdasarkan uraian di atas tampak bahwa pada siklus II ini belum sesuai dengan yang diharapkan karena masih mengalami beberapa kesulitan diantaranya adalah: (1) siswa masih bingung dalam menganalisis data hasil praktikum yang dihubungkan dengan materi yang dipelajari, (2) siswa belum begitu antusias dalam mengikuti pembelajaran di kelas.

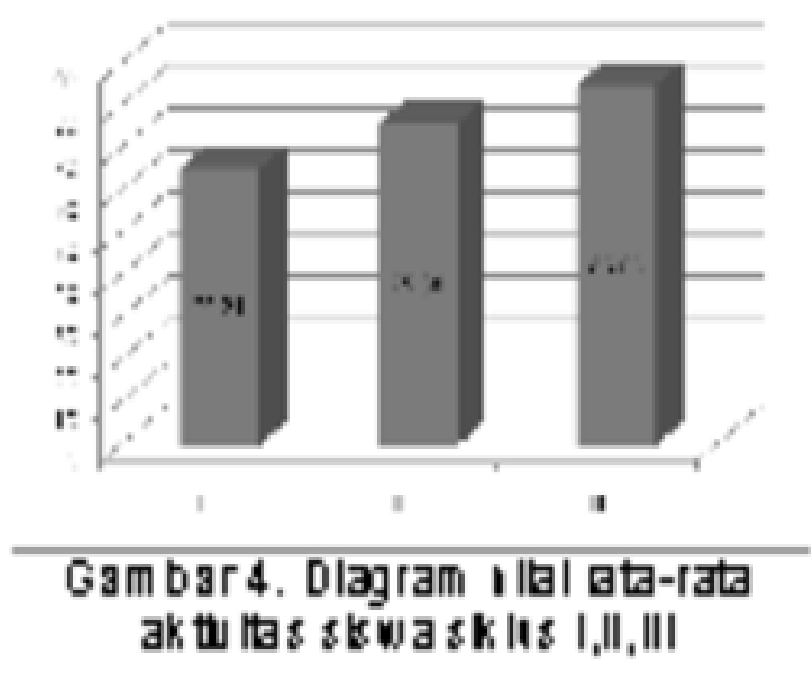

\section{Siklus III}

Pada pelaksanaan siklus I dan siklus II yang sudah dilakukan ternyata belum berhasil mencapai target sehingga perlu dilanjutkan ke siklus selanjutnya 
yaitu siklus III dengan harapan indikator keberhasilan dapat tercapai. Siklus III ini dilaksanakan sebanyak 3 pertemuan yang diakhiri dengan tes akhir siklus III. Dalam pelaksanaan siklus III ini peneliti mengacu pada refl eksi pada siklus II sehingga indikator keberhasilan dapat tercapai. Pada siklus III ini guru mengajak siswa untuk dapat menganalisis suatu masalah dalam kehidupan sehari-hari yang dihubungkan dengan materi yang akan dipelajari.

Misalnya dalam siklus 3 ini memasuki materi tekanan osmotik. Sebelum guru menjelaskan lebih lanjut tentang tekanan osmotik maka siswa diajak untuk berfi kir dikaitkan dengan contoh dalam kehidupan sehari-hari. Misalnya: Apabila wortel direndam dalam air (akuades) maka wortel akan mengembang, akan tetapi apabila wortel direndam dalam air garam maka wortel akan mengkerut. Hal itu terjadi karena adanya peristiwa osmosis yaitu dari larutan yang encer ke larutan yang pekat. Dengan demikian materi yang dipelajari oleh siswa tidak hanya dalam bentuk teori yang sudah tertuang dalam buku tetapi dikaitkan dengan kehidupan kita sehari-hari. Pada tes akhir siklus III ini diperoleh rata-rata nilai siswa adalah 89,88. Ketuntasan siswa meningkat sebesar $28,57 \%$ yang semula pada siklus II siswa yang tuntas sebanyak $70 \%$ pada siklus III meningkat menjadi $90 \%$. Aktivitas siswa ternyata mengalami peningkatan sebesar $12,08 \%$ yang semula pada siklus II rata-ratanya sebesar 75,88 meningkat menjadi 85,05. Rata-rata nilai psikomotorik siswa pada siklus III (praktikum yang kedua) adalah 85,044 dan masuk pada kriteria sangat baik serta peningkatan rata-rata psikomotoriknya dari siklus II ke siklus III ini sebesar 4,67\%.Sedangkan untuk persentase peningkatan ketuntasannya dari praktikum yang pertama ke praktikum yang kedua adalah sebesar $33,33 \%$. Pada aspek afektif rata-rata nilai pada siklus III ini adalah 85,09 dan masuk pada kriteria sangat baik, sedangkan untuk persentase peningkatan rata-ratanya dari siklus II adalah sebesar $15,03 \%$. Pada siklus III ,kinerja guru selama proses pembelajaran setelah dianalisis ternyata diperoleh skor 67,5. Adapun persentase kinerja guru sebesar $84,38 \%$ dan termasuk kriteria sangat baik. Dengan demikian dari siklus II ke siklus III kinerja guru mengalami peningkatan dengan persentase peningkatan sebesar $4,65 \%$.

\section{KESIMPULAN}

Berdasarkan hasil penelitian dan analisis data mengenai Peningkatan Hasil Belajar Siswa Melalui Pendekatan Keterampilan Proses Sains (KPS) Berorientasi Problem Based Instruction (PBI), maka peneliti memperoleh simpulan bahwa melalui Pendekatan Keterampilan Proses Sains (KPS) Berorientasi PBI dapat meningkatkan hasil belajar serta aktivitas belajar siswa.

\section{DAFTAR PUSTAKA}

Abdullah, Muhtadi. 2007. Pembelajaran Berbasis Masalah Pada Topik Wujud Zat Dan Perubahannya Untuk Meningkatkan Pemahaman Konsep Dan Keterampilan Proses Sains Siswa SMP. Tesis: Tidak diterbitkan.

Dimyati dan Mudjiono. 2002. Belajar dan Pembelajaran. Jakarta : Rineka Cipta.

Maretnowati, D. 2007. Peningkatan Hasil Belajar Kimia Pokok Materi Sistem Koloid Melalui Pendekatan Problem Based Instruction (PBI) dengan 
Menggunakan Kartu Masalah di Kelas XI Semester 2 SMAN I KarangPandan Tahun Pelajaran 2006/2007.Skripsi: Tidak diterbitkan.

Mansur, S dan Loli. M.P.P. 2019. Upaya Meningkatkan Hasil Belajar Siswa Kelas VII dengan Model Guide Note Taking di SMP San Karlos Habi. Uin Raden Intan Lampung. BIOSFER: Jurnal Tadris Biologi. 10 (1): 21-28. DOI: https://doi.org/10.24042/biosfer.v10i1.3990

Shofa, A. 2008. Peningkatan Kreativitas Dan Hasil Belajar Kimia Melalui Pendekatan Keterampilan Proses Pada Siswa Kelas XI IPA I SMA Negeri 12 Semarang Tahun Ajaran 2007/2008. Skripsi: Tidak diterbitkan

Sudarman. 2007. Problem Based Learning Suatu Model Pembelajaran untuk Mengembangkan dan Meningkatkan Kemampuan Memecahkan Masalah. dalam http://jurnalipi.wordpress. com/2007/10/01/sudarman/?referer=sphere related content/ (diunduh tanggal 28-06-2008

S, M., \& Bare, Y. (2019). Meningkatkan Hasil Belajar Siswa pada Konsep Perubahan dan Pelestarian Lingkungan Hidup dengan Model Discovery Learning di SMAS Katolik ST Gabriel Maumere. BIOEDUSCIENCE: Jurnal Pendidikan Biologi Dan Sains, 3(2), 84-89. https://doi.org/10.29405/j.bes/3284-893298

S, M. (2018). Pengaruh Pendekatan Jelajah Alam Sekitar (JAS) Terhadap Hasil Belajar Siswa pada Materi Klasifikasi Mahluk Hidup di SMPK Binawirawan Maumere. BIOEDUSCIENCE: Jurnal Pendidikan Biologi Dan Sains, 2(1), 74-80. https://doi.org/10.29405/j.bes/2174-801314 